\title{
MOŻLIWOŚCI ODZYSKU EGZERGII Z MODUŁU FOTOWOLTAICZNEGO UMIESZCZONEGO NA SKRZYDLE STATKU POWIETRZNEGO KLASY HALE Z WYKORZYSTANIEM ZJAWISK TERMOELEKTRYCZNYCH
}

\author{
Korneliusz Sierpowski, WieseaW Wróblewski, Ziemowit Malecha \\ Politechnika Wrocławska, Katedra Kriogeniki i Inżynierii Lotniczej, Wrocław \\ e-mail:korneliusz.sierpowski@pwr.edu.pl; wieslaw.wroblewski@pwr.edu.pl; ziemowit.malecha@pwr.edu.pl
}

\begin{abstract}
W pracy zaproponowano sposób odzysku egzergii z modułu fotowoltaicznego umieszczonego na skrzydle statku powietrznego klasy HALE z wykorzystaniem zjawisk termoelektrycznych. Przeprowadzono analizę numeryczną zaproponowanego rozwiązania. Pokazano wyniki współpracy modułu fotowoltaicznego z modułem termoelektrycznym. Przedstawiono różnicę pomiędzy modułem fotowoltaicznym pracującym jako samodzielne źródło energii elektrycznej a modułem fotowoltaicznym sprzężonym z modułem termoelektrycznym. Pokazano, że w pewnych warunkach zaproponowane rozwiązanie korzystnie wpływa na zwiększenie produkcji energii z jednostki powierzchni. W pracy przeprowadzono także dyskusję nad możliwościami wykorzystaniem proponowanego rozwiązania, uwzględniając obecny stan wiedzy dotyczacy materiałów termoelektrycznych.
\end{abstract}

\section{Wstęp}

Bezzałogowe statki powietrzne klasy HALE (ang. High Altitude Long Endurance) są wykorzystywane do wypełniania zadań długotrwałych, podczas których musi znajdować się na pułapie operacyjnym [1]. Ze względu na powyższe wymagania, statek taki powinien być bardzo lekki oraz w sposób optymalny wykorzystywać dostępne źródła energii. W związku z ograniczoną ilością paliwa (takiego jak skroplony lub gazowy wodór, skroplony gaz ziemny, amoniak, hydrazyna i pokrewne związki chemiczne), jakie taki statek może wynieść, obecne wysiłki skupiają się między innymi nad maksymalizacją uzysku energetycznego z dostępnych w stratosferze źródeł energii - energii słonecznej [1]. Ten rodzaj energii pierwotnej jest następnie przetwarzany na energię elektryczną.

Moduł fotowoltaiczny (zwany dalej PV) to układ połączonych elektrycznie szeregowo, równolegle lub szeregowo-równolegle ogniw fotowoltaicznych. Ogniwa fotowoltaiczne wykorzystują zjawisko fotowoltaiczne, które jako pierwszy odkrył A.C. Becquerel w 1839 roku [2]. Obecnie najsprawniejsze dostępne na rynku moduły GaAs wykonane w technologii triple junction osiągają sprawności przetwarzania sięgające nawet 34\% [3]. Fotowoltaika przetwarza część zaabsorbowanego promieniowania słonecznego bezpośrednio na energię elektryczną. Pozostała część zaabsorbowanego promieniowania słonecznego jest oddawana do otoczenia poprzez mechanizm konwekcji oraz promieniowanie.

Generatory termoelektryczne, zwane również modułami termoelektrycznymi, to układ połączonych elektrycznie szeregowo, równolegle lub szeregowo-równolegle par złącz termoelektrycznych, obecnie wykonywanych najczęściej z półprzewodników [4]. Do grupy zjawisk termoelektrycznych zalicza się zjawisko Seebecka, zjawisko Peltiera i zjawisko Thompsona [4], jednakże szczegółowa analiza tych zjawisk nie będzie przedmiotem tego artykułu. Moduł termoelektryczny (zwany dalej TEG) wytwarza energię elektryczną dzięki występującemu gradientowi temperatur pomiędzy okładzinami modułu oraz wynikającemu z gradientu temperatur przepływowi ciepła. 
Sprawność TEG zależy między innymi od gradientu temperatur, jednakże zazwyczaj nie wynosi więcej niż $10 \%$.

Termin „egzergia” został wprowadzony w 1955 roku przez fizyka Zorana Ranta. Zgodnie z definicją [5] jest to maskymalna praca, jaką układ termodynamicznie otwarty może wykonać w danym otoczeniu, przechodząc do stanu równowagi z otoczeniem. Wykorzystanie egzergii jest jednoznaczne z jej destrukcją. W tym przypadku źródłem egzergii jest niewykorzystana energia cieplna pochodząca z nieprzetworzonego na energię elektryczną strumienia zaabsorbowanej energii słonecznej.

W niniejszej pracy zaproponowano możliwość odzysku egzergii modułu fotowoltaicznego umieszczonego na skrzydle statku powietrznego klasy HALE w warunkach stratosferycznych z wykorzystaniem zjawisk termoelektrycznych. Odzysk egzergii ma zachodzić poprzez przepływ części strumienia ciepła pochodzącego z PV poprzez TEG do atmosfery.

\section{Model matematyczny}

Model zakłada ustalone przewodzenie i wnikanie ciepła przedstawione na rysunku 1. Można wyszczególnić dwie płaskie płyty ustawione horyzontalnie, przepływ powietrza jest do nich równoległy. Górna płaska płyta imituje moduł fotowoltaiczny PV, natomiast dolną płaską płytę można interpretować jako spodnią część poszycia skrzydła. Symbolicznie pokazano moduł termoelektryczny TEG, którego górną okładziną jest PV, natomiast dolną okładziną jest spodnia część poszycia skrzydła. W sposób schematyczny pokazano dopływające i odpływające strumienie energii.

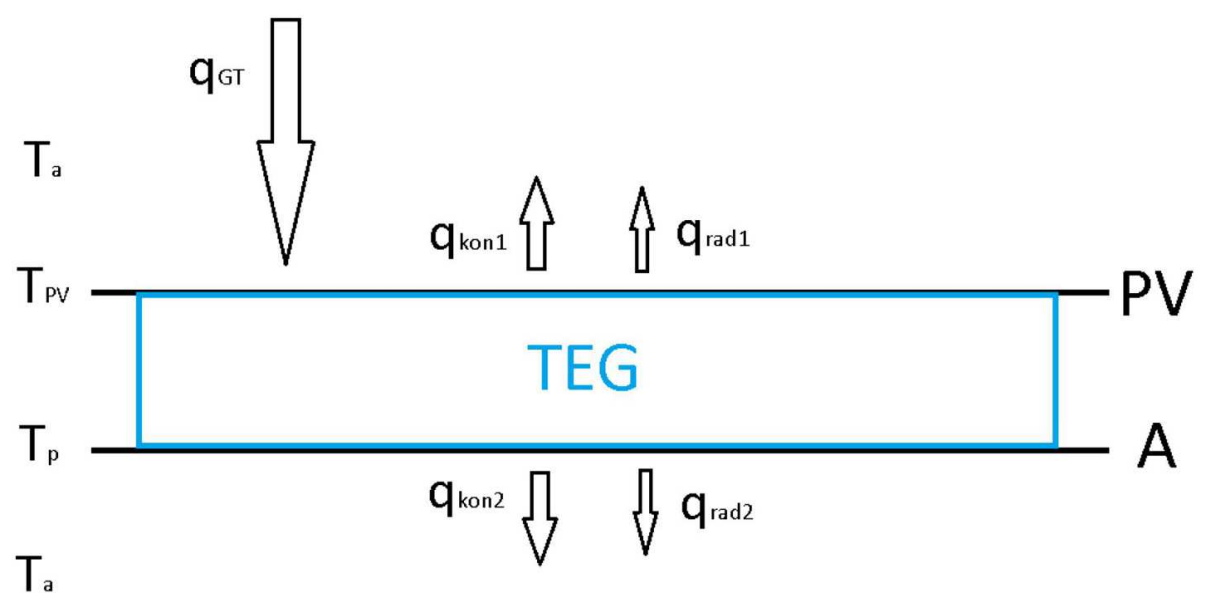

Rys. 1. Schemat ideowy odzysku egzergii z PV z wykorzystaniem TEG; $q_{G T}$ - strumień energii słonecznej, $q_{k o n 1}$ - strumien ciepła oddany poprzez konwekcję wymuszoną z górnej płyty (PV),

$q_{\text {kon2 }}$ - strumien ciepła oddany poprzez konwekcję wymuszoną z dolnej płyty $(\mathrm{A}), q_{\text {rad }}$ - strumien ciepła wypromieniowany z górnej płyty $(\mathrm{PV}), q_{\text {rad2 }}$ - strumien ciepła wypromieniowany

$\mathrm{z}$ dolnej płyty (A), $T_{P V}$ - temperatura modułu fotowoltaicznego, $T_{a}$ - temperatura otoczenia, $T_{p}$ - temperatura dolnej płyty

Na podstawie modelu atmosfery NASA [6] ustalono, że na pułapie między $11000 \mathrm{~m}$ n.p.m. a $25000 \mathrm{~m}$ n.p.m otoczenie osiąga temperaturę około $217 \mathrm{~K}$. Ciśnienie atmosferyczne jest funkcją wysokości n.p.m.

$$
p=22,65 \exp (1.73-0.000157 h)
$$

Na podstawie ciśnienia i temperatury otoczenia określane są konwekcyjne współczynniki przejmowania ciepła. W tym artykule przyjęto, że prędkość przepływu powietrza jest stała i wynosi $v=15 \mathrm{~m} / \mathrm{s}$. Dla tych warunków liczba Nusselta wynosi $N u=162,65$, a liczba Reynoldsa 
$R e=82500$. Konwekcyjny współczynnik przejmowania ciepła dla płaskiej płyty w położeniu horyzontalnym wynosi $h_{k o n}=4,24 \mathrm{~W} /\left(\mathrm{m}^{2} \mathrm{~K}\right)$. Strumień ciepła oddany z górnej płyty poprzez zjawisko konwekcji wymuszonej oraz promieniowanie jest opisany odpowiednio przez równania $(2.2)_{1}$ i $(2.2)_{2}$. Strumień ciepła oddany z dolnej płyty poprzez zjawisko konwekcji wymuszonej oraz promieniowania jest opisany odpowiednio przez równania $(2.3)_{1}$ i $(2.3)_{2}$. Emisyjność powierzchni płyt zostały oznaczone jako $\varepsilon_{1}$ oraz $\varepsilon_{2}$. Stałą Boltzmana oznaczono jako $\sigma$

$$
\begin{array}{lc}
q_{r a d 1}=\varepsilon_{1} \sigma\left(T_{P V}^{4}-T_{a}^{4}\right) & q_{k o n 1}=h_{k o n}\left(T_{P V}-T_{a}\right) \\
q_{r a d 2}=\varepsilon_{2} \sigma\left(T_{p}^{4}-T_{a}^{4}\right) & q_{k o n 2}=h_{k o n}\left(T_{p}-T_{a}\right) \\
q_{1}=q_{k o n}+q_{r a d 1} & q_{2}=q_{k o n 2}+q_{r a d 2}
\end{array}
$$

Stan równowagi zostaje osiągnięty po spełnieniu warunku równowagi między strumieniem energii słonecznej a strumieniami ciepła oddanego do otoczenia

$$
q_{G T}=q_{1}+q_{2}
$$

Strumień energii słonecznej docierającej do powierzchni PV i zaabsorbowanej jako ciepło można określić za pomocą równania

$$
q_{G T}=G T\left(\tau \alpha-\eta_{P V}\right)
$$

gdzie: $\tau$ - współczynnik transmitancji, $\alpha$ - współczynnik absorpcji, $G T$ - stała słoneczna oraz $\eta_{P V}$ - sprawność modułu fotowoltaicznego. Temperaturę modułu fotowoltaicznego można określić za pomocą równania

$$
T_{P V}=T_{a}+\frac{G T}{U}\left(\tau \alpha-\eta_{P V}\right)
$$

Kluczowym elementem jest rachunek wypadkowego współczynnika przejmowania ciepła $U$ przez otoczenie (równanie $(2.8)_{1}$ ). Współczynnik ten determinuje strumień oddawanego ciepła z danej płyty oraz temperaturę $P V$

$$
\begin{array}{ll}
U=U_{1}+U_{2} & q_{2}=\frac{U_{2}}{U} q_{G T} \\
\frac{1}{U_{1}}=\frac{1}{h_{\text {kon }}+h_{\text {rad } 1}} & \frac{1}{U_{2}}=\frac{1}{h_{T E G}}+\frac{1}{h_{k o n}+h_{\text {rad } 2}}
\end{array}
$$

Współczynnik przenikania ciepła TEG można określić za pomocą równania

$$
h_{T E G}=\frac{x \kappa}{l}
$$

gdzie: $x$ - współczynnik wypełnienia TEG, $\kappa$-przewodność cieplna TEG oraz $l$-długość elementu termoelektrycznego (wzdłuż kierunku wymiany ciepła). Sprawność modułu termoelektrycznego sprzężonego z modułem fotowoltaicznym w konfiguracji pokazanej na rys. 1, można opisać równaniem [5]

$$
\eta_{T E G}=\frac{T_{P V}-T_{p}}{T_{P V}} \frac{\sqrt{Z T+1}-1}{\sqrt{Z T+1}+\frac{T_{p}}{T_{P V}}}
$$

gdzie: $Z T$ - dobroć termoelektryczna charakteryzująca bezwymiarowo wykorzystany półprzewodnik w module termoelektrycznym. Sprawność egzergetyczną układu PV-TEG można opisać jako $[7]$

$$
\begin{array}{lc}
\eta_{E X}=\frac{E_{E X P V}+E_{E X T E G}}{E_{E X i n}} & E_{E X P V}=P_{P V}=A \eta_{P V} G T \\
E_{E X T E G}=P_{T E G}=A \eta_{T E G} q_{2} & E_{E X i n}=A G T \varphi \\
\varphi=1+\frac{1}{3}\left(\frac{T_{a}}{T_{\text {sun }}}\right)^{4}-\frac{4}{3} \frac{T_{a}}{T_{\text {sun }}} &
\end{array}
$$


gdzie: $E_{E X P V}$ - ilość egzergii zniszczonej przez PV, $E_{E X P V}$ - ilość egzergii zniszczonej przez TEG, $E_{E X i n}$ - egzergia promieniowania słonecznego, $T_{\text {sun }}$ - temperatura słońca $(6000 \mathrm{~K})$, $\varphi$ - równanie Peteli.

Na potrzeby dalszej analizy zaproponowanego rozwiązania przeprowadzono obliczenia numeryczne dla równań (2.2)-(2.10) dla szukanych temperatur $T_{P V}$ oraz $T_{p}$.

\section{Wyniki rozwiązania numerycznego}

Na potrzeby obliczeń założono $\tau \alpha=0.9$ [8]. Parametry modułu termoelektrycznego użytego do dalszych rozważań to $l=0.1 \mathrm{~m}, \kappa=2,6 \mathrm{~W} /\left(\mathrm{m}^{2} \mathrm{~K}\right), x=60 \%$ oraz $Z T=1$. Wartości te odnoszą się do rzeczywistych własności materiałowych TEG. Założono, że sprawność PV jest stała i wynosi $\eta_{P V}=30 \%$. Na potrzeby analizy przyjęto stałą słoneczną GT w zakresie od 0 do $1200 \mathrm{~W} / \mathrm{m}^{2}$. Zmienna wartość stałej słonecznej symuluje zmienne warunki oświetlenia PV. $\mathrm{W}$ dalszych obliczeniach przyjęto wielkość powierzchni równą $1 \mathrm{~m}^{2}$.

- Emisyjność PV $\varepsilon_{1}=0$ oraz emisyjność dolnej płyty $\varepsilon_{2}=0.9$

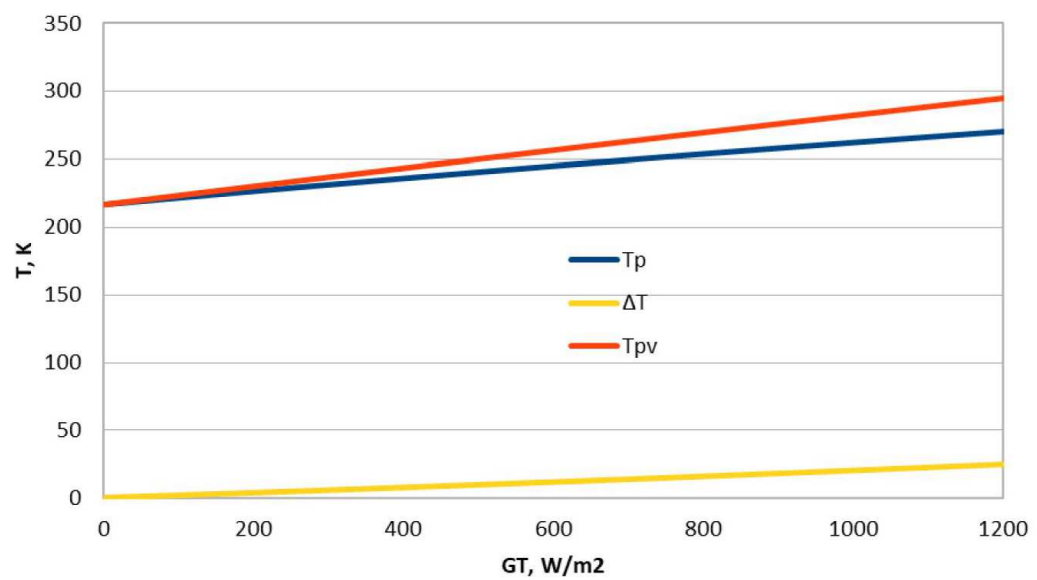

Rys. 2. Temperatury PV oraz dolnej płyty w funkcji strumienia energii słonecznej; $\Delta T$ - różnica pomiędzy tymi temperaturami

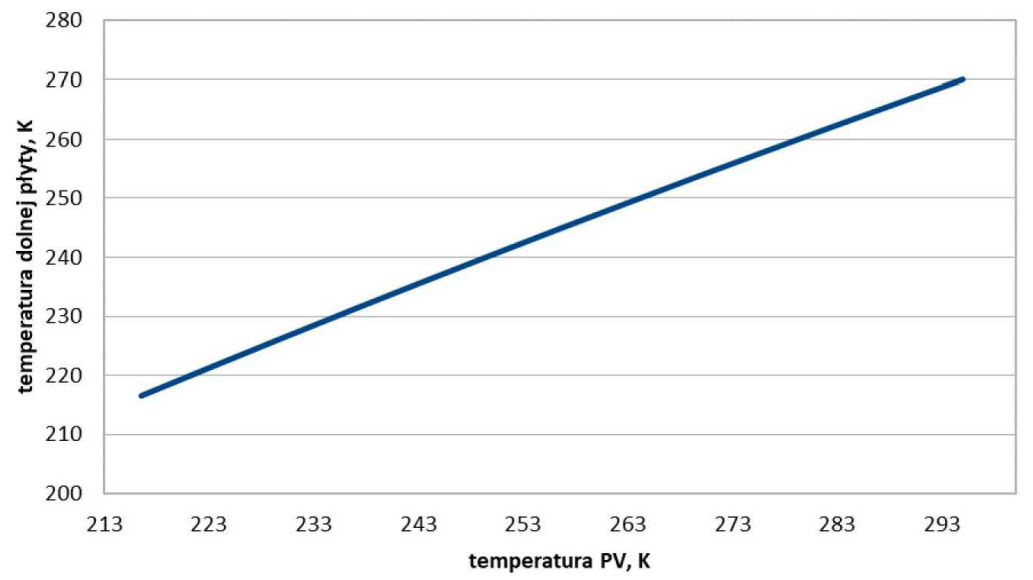

Rys. 3. Zależność temperatury dolnej płyty w funkcji temperatury PV dla proponowanego w artykule rozwiązania

Analizując rysunki 2, 3 i 4, można wywnioskować, że dla założonych warunków odzysk egzergii jest możliwy. Dla założonych warunków maksymalny wzrost całkowitej sprawności układu 


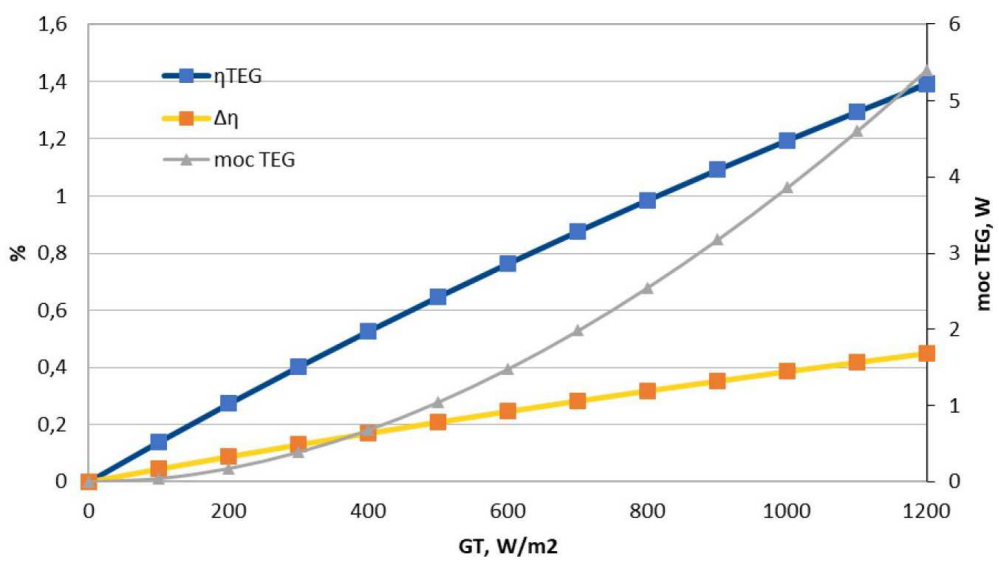

Rys. 4. Sprawność TEG oraz moc TEG w funkcji strumienia energii słonecznej; $\Delta \eta$ - różnica ogólnej sprawności tandemu PV-TEG względem samego PV

PV-TEG względem PV wynosi ponad 0,4 punkta procentowego. Oznacza to wzrost produkcji energii elektrycznej z jednostki powierzchni o ponad $5 \mathrm{~W}$. Dzięki takiemu rozwiązaniu można zwiększyć wykorzystanie energii słonecznej z jednostki powierzchni w warunkach stratosfery.

- Emisyjność PV $\varepsilon_{1}=0.3$ oraz emisyjność dolnej płyty $\varepsilon_{2}=0.9$

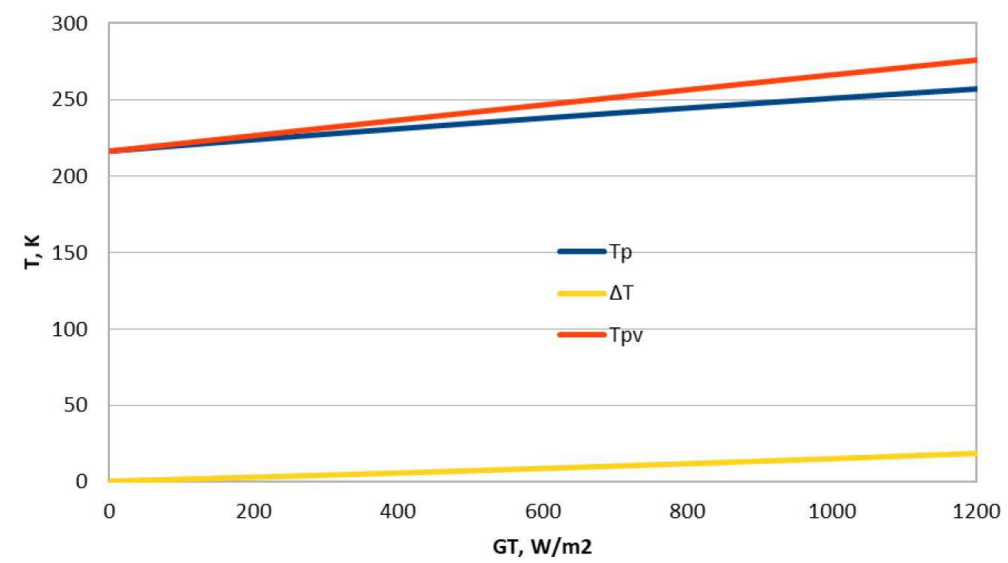

Rys. 5. Temperatury PV oraz dolnej płyty w funkcji strumienia energii słonecznej; $\Delta T$ - różnica pomiędzy tymi temperaturami

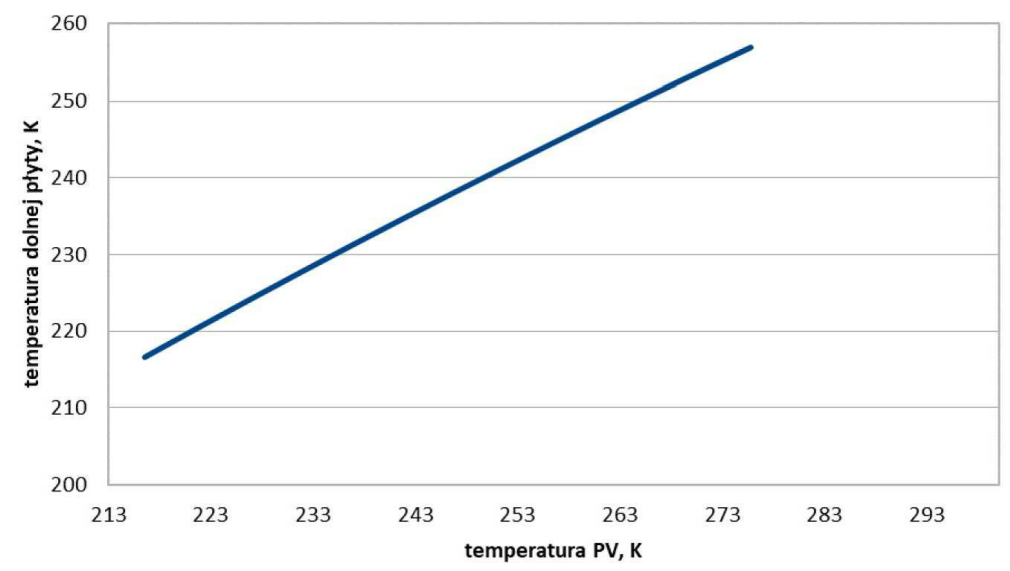

Rys. 6. Zależność temperatury dolnej płyty w funkcji temperatury PV dla proponowanego $\mathrm{w}$ artykule rozwiązania 


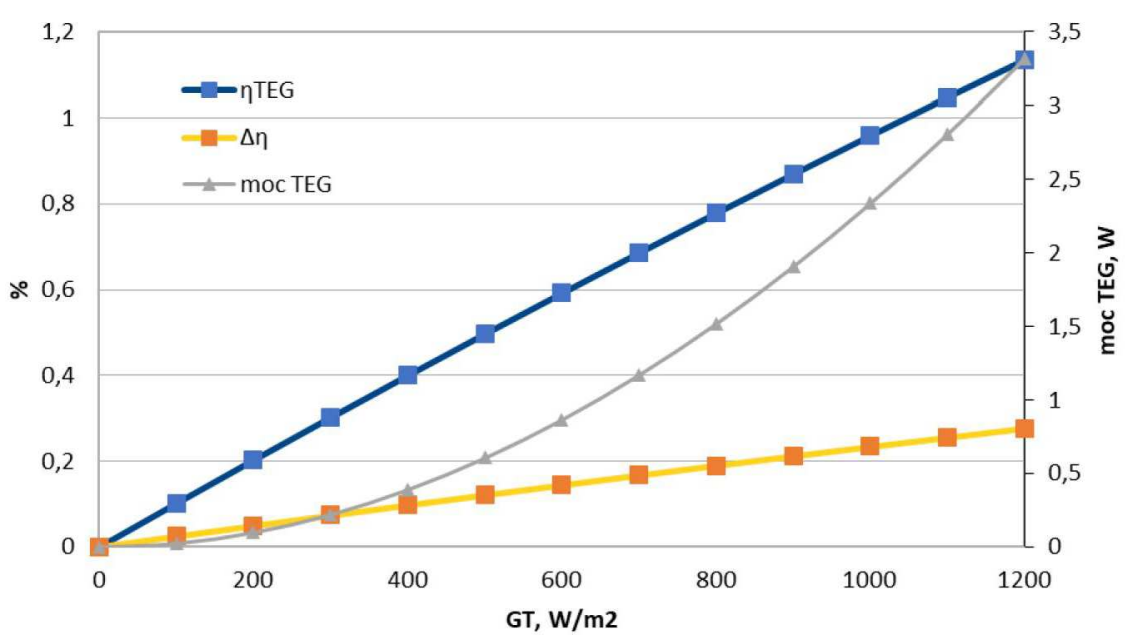

Rys. 7. Sprawność TEG oraz moc TEG w funkcji strumienia energii słonecznej; $\Delta \eta$ - różnica w ogólnej sprawności tandemu PV-TEG względem samego PV

Analizując rysunki 5,6 i 7, można wywnioskować, że dla założonych warunków odzysk egzergii jest możliwy. Dla założonych warunków maksymalny wzrost całkowitej sprawności układu PV-TEG względem PV wynosi około 0,2 punkta procentowego. Oznacza to wzrost produkcji energii elektrycznej z jednostki powierzchni o ponad $3 \mathrm{~W}$. Dzięki takiemu rozwiązaniu można zwiększyć wykorzystanie energii słonecznej z jednostki powierzchni w warunkach stratosfery.

- Porównanie efektu odzysku egzergii dla $\varepsilon_{1}=0$ oraz $\varepsilon_{1}=0.3$

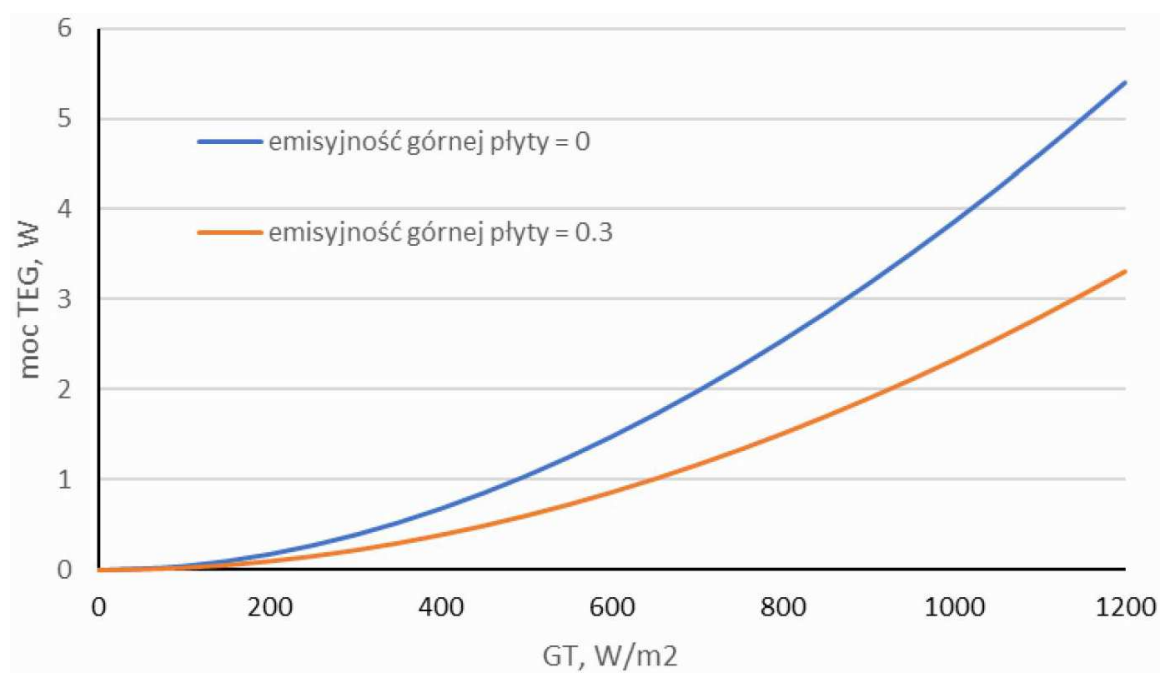

Rys. 8. Na wykresie pokazano wpływ wartości emisyjności PV na ogólny efekt odzysku egzergii z PV

Na podstawie rys. 8 wywnioskowano, że pokrywanie modułów fotowoltaicznych pokryciami o bardzo niskiej emisyjności ma korzystny wpływ na efekt energetyczny rozwiązania.

- Temperatura PV w funkcji strumienia energii słonecznej przy $\varepsilon_{1}=0$ oraz $U_{2}=0$

Na podstawie rys. 9 wywnioskowano, że dla konwencjonalnego montażu fotowoltaiki na skrzydle samolotu, czyli zakładając bardzo dobrą izolację termiczną po spodniej stronie PV, temperatura PV jest wyższa $\mathrm{w}$ warunkach stratosfery niż dla rozwiązania PV-TEG. Oznacza to, że umożliwienie wymiany ciepła po obu stronach PV zmniejsza jego temperaturę. 


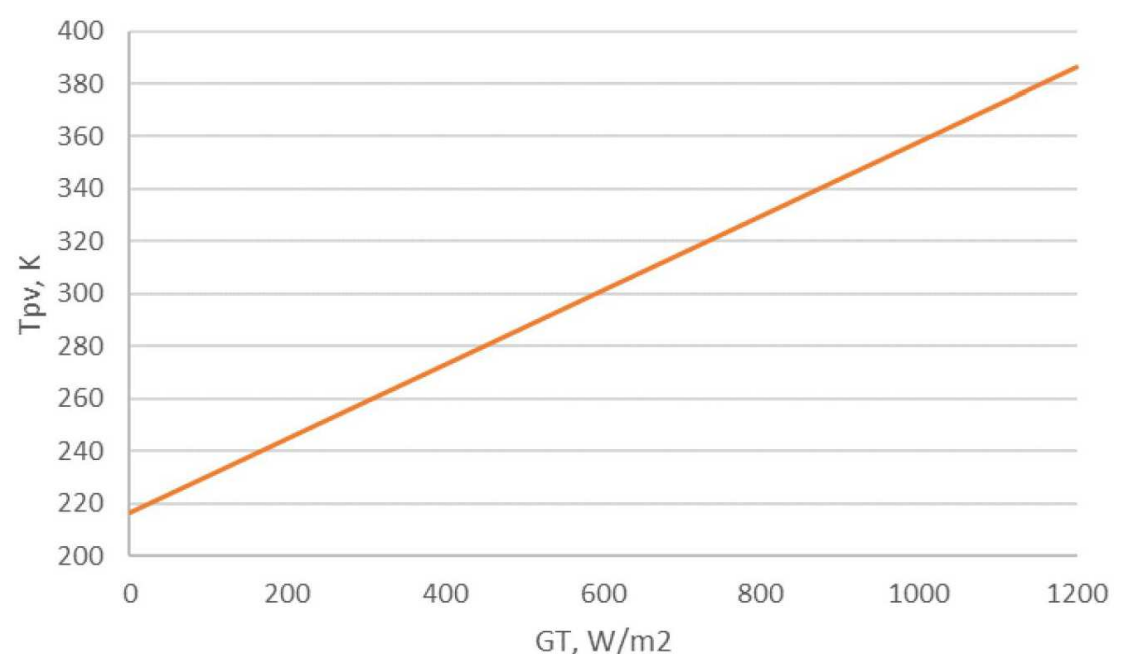

Rys. 9. Temperatura PV w konwencjonalnym wykonaniu z emisyjnością $\varepsilon_{1}=0$. Założono idealną izolację termiczną po spodniej stronie PV

- Sprawność egzergetyczna układu PV-TEG względem PV przy $\varepsilon_{1}=0$

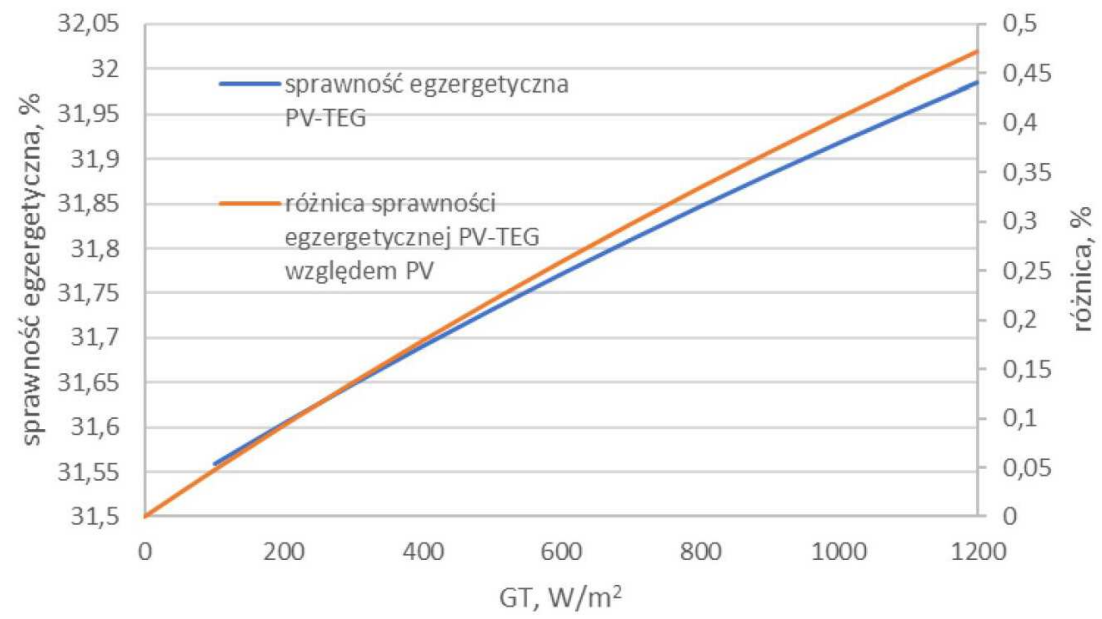

Rys. 10. Sprawność egzergetyczna układu PV-TEG względem PV

Zauważono, że zastosowanie modułu termoelektrycznego pozwala na zwiększenie sprawności energetycznej oraz sprawności egzergetycznej. Oznacza to zwiększenie destrukcji egzergii w układzie PV-TEG względem PV o nawet 0,5 punktu procentowego.

\section{Podsumowanie}

Celem powyższych badań było stwierdzenie możliwości odzysku egzergii z modułu fotowoltaicznego umieszczonego na skrzydle statku powietrznego klasy HALE. Dzięki prezentowanym charakterystykom można stwierdzić, że taka możliwość istnieje.

Jednym z ważniejszych wniosków tej pracy jest wykazanie możliwości podniesienia sprawności układu PV-TEG względem PV o maksymalnie około 0,4 punkta procentowego przy zastosowaniu na górnej części układu PV-TEG powłoki o niskiej emisyjności. Dzięki temu sprawność PV-TEG względem PV może zostać zwiększona z zakładanego poziomu $30 \%$ do ponad 30,4\%. Przekłada się to na zwiększoną moc układu o ponad 5 W. Jednocześnie temperatura PV jest 
obniżana dzięki zwiększeniu wymiany ciepła z otoczeniem, co ma korzystny wpływ na jej żywotność oraz zmniejszenie dobowych wahań temperatury PV oraz może spowodować naprężenia termiczne i wynikające $\mathrm{z}$ tego uszkodzenia mechaniczne.

Przy założeniu niezerowej emisyjności PV $\varepsilon_{1}=0.3$ zauważono mniejszy wzrost sprawności układu - zaledwie o ponad 0,2 punktu procentowego, co przekłada się na zwiększenie mocy o ponad $3 \mathrm{~W}$.

Zauważono, że układ PV-TEG zaproponowany w niniejszej pracy pozwala na zwiększenie destrukcji egzergii względem PV o maksymalnie około 0,5 punktu procentowego.

Kolejnym wnioskiem płynącym z analizy jest opłacalność pokrywania fotowoltaiki pokryciami o bardzo niskiej emisyjności, jednakże tylko w przypadku układu PV-TEG. Powłoki takie są dostępne na rynku [9], co pozwala na szybkie wdrożenia rozwiązania.

Jedyną obecnie przeszkodą do wdrożenia rozwiązania w lotnictwie jest geometria modułu termoelektrycznego i wysoka średnia gęstość materiałów termoelektrycznych. Autorzy prowadzą prace związane z optymalizacją geometrii i możliwości znacznej redukcji masy TEG przy zachowaniu podobnego poziomu osiąganej sprawności.

\section{Bibliografia}

1. NASA Armstrong Fact Sheet: Helios Prototype, NASA, 28 luty, 2014

2. Palz W., Power for the World - The Emergence of Electricity from the Sun, Belgia, Pan Stanford Publishing, ISBN 9789814303385, 2010

3. http://www.azurspace.com/images/0003569-02-00_DB_TJ_Solar_Cell-Assembly_3T34A.pdf (Stan na dzień 01.10.2020)

4. Rowe D.M., Thermoelectrics Handbook: Macro to Nano, Taylor \& Francis, ISBN 0-8493-2264-2, 2006

5. Rant Z., Exergie, ein neues Wort für „Technische Arbeitsfahigkeit”, Forschung Auf dem Gebiete des Ingenieurwesens, 22, 36-37, 1956

6. Standard Atmosphere, International Organization for Standardization, ISO 2533:1975, 1975

7. Shittua S., Lia G., Zhao X., Zhou J., Ma X., Akhlaghi Y.G., Experimental study and exergy analysis of photovoltaic-thermoelectric with flat plate micro-channel heat pipe, Energy Conversion and Management, 207, 112515, 2020

8. Duffie J.A., Beckman W.A., Solar Engineering of Thermal Processes, Solar Energy Laboratory, University of Wisconsin-Madison, 4th Ed., ISBN 978-0-470-87366-3, 2013

9. 2009 ASHRAE Handbook: Fundamentals - IP Edition, Atlanta, American Society of Heating, Refrigerating and Air-Conditioning Engineers, ISBN 978-1-933742-56-4, 2009

\section{Possibility of exergy recovery from a photovoltaic module in combination with thermoelectric effects located on a wing of HALE aerial vehicle}

This work shows the possibility of exergy recovery from a photovoltaic module coupled with thermoelectric effects and located on a wing of HALE aerial vehicle. Numerical analysis of the proposed solution was conducted. The obtained results were focused on a possible gain from cooperation of the photovoltaic and thermoelectric module. It was shown that in certain situations, the proposed solution could achieve higher energy production from a unit area. The paper also discusses the potential use of the proposed solution using the current state of knowledge on thermoelectric materials. 